\title{
META-ANALYSIS THE EFFECT OF OBESITY IN MENSTRUAL CYCLE DISORDER
}

\author{
Lutfi Annarahayu1), Yulia Lanti Retno Dewi²), \\ Rita Benya Adriyani3) \\ ${ }^{1)}$ Masters Program in Public Health, Universitas Sebelas Maret \\ ${ }^{2)}$ Faculty of Medicine, Universitas Sebelas Maret \\ 3)Department of Occupational Therapy, Health Polytechnics, \\ Ministry of Health Surakarta
}

\begin{abstract}
Background: Many women of reproductive age suffer dysmenorrhea and irregular menstrual bleeding, which can lead to serious problems even infertility. Previous studies examine the possibility that overweight and obesity play a role in menstrual problems. This study aimed to investigate the effect of obesity in menstrual cycle disorder.

Subjects and Method: A systematic review and meta-analysis was conducted by collecting articles from PubMed, ScienceDirect, and Google Scholar. The study population was women of reproductive age. Intervention was obesity with comparison was normal weight. Outcome was menstrual cycle disorder. Keywords used "obesity" AND menstrual irregularity OR menstrual disorder AND cross sectional study". The inclusion criteria were full text and cross sectional study. Selected articles were assessed by Review Manager $5 \cdot 3$.

Results: Meta-analysis involving 8 observational studies showed that obese women of reproductive age were at risk to experience menstrual cycle disorder 4 times than those with normoweight $(\mathrm{aOR}=4.19 ; 95 \% \mathrm{CI}=1.99$ to $8.84 ; \mathrm{p}=0.002)$.
\end{abstract}

Conclusion: Obesity increases menstrual cycle disorder.

Keywords: obesity, menstrual cycle disorder

\section{Correspondence:}

Lutfi Annarahayu. Masters Program in Public Health, Universitas Sebelas Maret. Jl. Ir. Sutami 36A, Surakarta 57126, Central Java, Indonesia. Email: Lutfi.annarahayu@student.uns.ac.id. Mobile: 081910979054 